Lagenidium callinectes infection on rotifers Brachionus sp. (Des Roza)

\title{
Lagenidium callinectes INFECTION ON ROTIFERS Brachionus sp.
}

\author{
Des Roza*) and Fris Johnny*)
}

\begin{abstract}
Milkfish, Chanos chanos and humpback grouper, Cromileptes altivelis hatcheries have developed at Gondol, Bali since 1995 and until now still rely on rotifers, the main natural food, supply. Recent problem on mass culture of rotifer, Brachionus sp. is harvest failure caused by fungus infection. Under light microscope, infected eggs and bodies of the rotifers was filled with numerous aseptate hyphae. Two isolates of fungi were isolated from rotifer eggs and carcass on June $21^{\text {st }}, 2004$ and on June $25^{\text {th }}$, 2004 obtained from milkfish and humpback grouper hatcheries at Gondol. Based on its morphological characteristics, the pathogenic fungus was identified as Lagenidium callinectes which grows optimally at $25^{\circ} \mathrm{C}$ and survives in $1.0 \% 2.5 \%$ and $5.0 \% \mathrm{NaCl}$ as well as in 1.0 and $2.5 \% \mathrm{KCl}$. Both of the present isolates utilize only 8 out of 26 carbohydrates and derivatives tested as carbon, nutrition and energy sources. This finding is the first report on rotifer, Brachionus sp. infected with L. callinectes causing up to $100 \%$ mortality.
\end{abstract}

\section{KEYWORDS: rotifers, milkfish, humpback grouper, Lagenidium callinectes}

\section{INTRODUCTION}

Some fungi belonging to the order Lagenidiales were previously found to be parasites of rotifers. They were identified as Olpidium Gregarium Schroet, Myzocytium Zoophthorum Sparrow and Lagenidium oophilum Sparrow (Sparrow In Nakamura \& Hatai, 1994) although the scientific names of the rotifers were not given. Karling (1981) has reported M. microsporum Sparrow, L. distylae Karling, and L. parthenosporum Karling as parasites of various rotifers including Distyla sp., Philodina sp., and Heterodera sp. Barron (1989) also found L. oviparasiticum Barron on eggs of Adineta sp. Recently, Comps et al. (1993) isolated Lagenidium like fungus from rotifer, Brachionus plicatilis Muller. However, Nakamura \& Hatai (1994) and Nakamura \& Hatai $\left(1995^{\mathrm{a}}\right.$ ) have been succeeded to isolated fungi member of the order Lagenidiales belonging to the genus of Atkinsiella namely A. parasitica from rotifer, B. plicatilis Muller.

Rotifers, Brachionus sp. is the first food for seed production of milkfish and humpback grouper in hatcheries at Gondol, Bali. Recent rotifers mortalities occurrence is suspected due to fungus infection. This paper reports the isolation and identification of the fungus obtained from milkfish and grouper hatchery, based on its morphological and biological characteristics, including nutritional study.

\section{MATERIALS AND METHODS}

Isolation and identification. Infected rotifers, Brachionus sp. were examined under light microscope. Rotifers, selected from infected samples with fungus infection as indicated by the presence of hyphae, were inoculated onto peptone- yeast extractglucose- seawater (PYGS) agar plate (composed of $1.25 \mathrm{~g}$ of Bacto peptone, $1.25 \mathrm{~g}$ of Bacto yeast extract, $3 \mathrm{~g}$ of glucose, $12 \mathrm{~g}$ of Bacto agar in $1,000 \mathrm{~mL}$ seawater) added with $500 \mathrm{mg}$ $\mathrm{mL}^{-1}$ streptomycin sulphate and ampicillin to retard bacterial contamination (Hatai, 1989). The cultures were then incubated at $25^{\circ} \mathrm{C}$ for 3 days. A small block agar with fungus mycelium was cut out and then inoculated onto

*) Research Institute for Mariculture, Gondol, Bali, Indonesia 
fresh PYGS agar to make a pure culture and used for all experiments. For morphological observation and identification, the fungus were inoculated into PYGS broth and incubated at 25C for 3 days. The small colonies in PYGS broth were transferred into sterilized seawater and incubated at $25^{\circ} \mathrm{C}$ to induce zoospore production. Zoospore germination was observed under microscope when were incubated in PYGS broth at $25^{\circ} \mathrm{C}$. The isolates were identified according to Karling (1981), Hatai (1989), and Nakamura \& Hatai (1995 ${ }^{\text {b). }}$

Effect of temperature on vegetative growth. Range and optimum temperature for vegetative growth were examined using mycelia. Each isolate was inoculated onto PYGS agar and incubated at $25^{\circ} \mathrm{C}$ for 7 days to produce a giant colony. Inocula were taken from the edge of each giant colony with a no. 2 cork borer ( $5.5 \mathrm{~mm}$ diameter) and inoculated onto PYGS agar plates. Each medium was prepared with $25 \mathrm{~mL}$ of PYGS agar in plastic Petri dish (8.25 cm diameter). Plates were incubated at 7 different temperatures, i.e. $10^{\circ} \mathrm{C}$, $15^{\circ} \mathrm{C}, 20^{\circ} \mathrm{C}, 25^{\circ} \mathrm{C}, 30^{\circ} \mathrm{C}, 35^{\circ} \mathrm{C}$, and $40^{\circ} \mathrm{C}$. The growth rate was observed by measuring the colony diameter after $1,3,5,7,10$, and 15 days then compared with $\mathrm{L}$. callinectes ATCC 200337 isolated from egg of swimming crab, Portunus pelagicus Linnaeus (Nakamura \& Hatai, $1995^{\mathrm{b}}$ ).

Mineral requirements for vegetative growth. The fungi were inoculated onto PYG agar containing various concentrations of $\mathrm{NaCl}$ or $\mathrm{KCl}$ to determine whether those minerals were required for vegetative growth. PYG agar was prepared using distilled water instead of seawater. PYG agar was mixed with $\mathrm{NaCl}$ or $\mathrm{KCl}$ at concentrations of $1.0 \% 2.5 \%$ and $5.0 \%(\mathrm{w} /$ v). PYGS and PYG agars were used as a control media. Inoculation and measurement of the colony diameter followed method for the experiment on effect of temperature and compared with those of L. callinectes ATCC 200337.

Nutritional study. Samples of three- days old cultured on PYGS agar were removed with no. 2 cork borer and inoculated into $20 \mathrm{~mL}$ PYS agar (formula as PYGS, with the usual base replaced by yeast extract carbon base) containing $0.5 \%(\mathrm{w} / \mathrm{v})$ of individual carbohydrates and derivatives. The colony diameters were measured after $1,3,5,7,10$ and 15 days incubation at $25^{\circ} \mathrm{C}$ in comparison with L. callinectes ATCC 200337.

\section{RESULTS}

Incidence. In mid year 2004, fungus infection occurred in eggs and bodies of rotifers, Brachionus sp. reared in hatchery at Gondol-Bali, and the population could not increase. The rotifers were cultured in a concrete tank as the first food supply for milkfish and humpback grouper seed production. Under microscopic observation, aseptate stout hyphae fill rotifers eggs and bodies (Figure 1-2). Final mortality due to the infection was reaching $100 \%$ From these
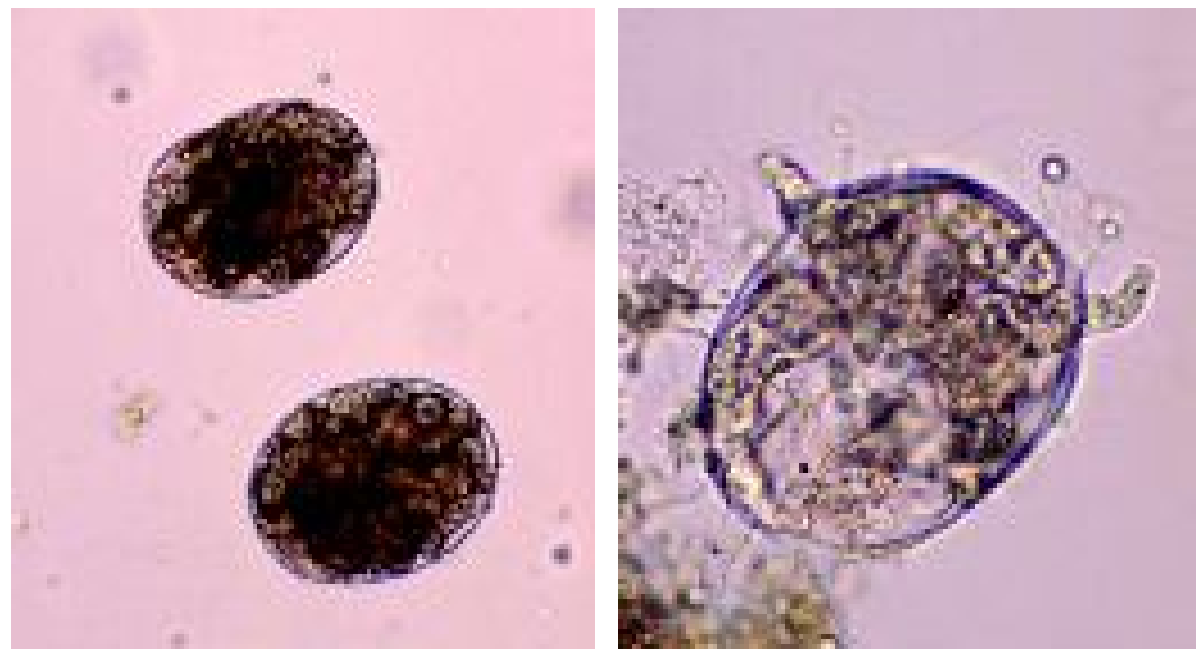

Figure 1. Natural fungal infection in rotifers, Brachionus sp. egg 


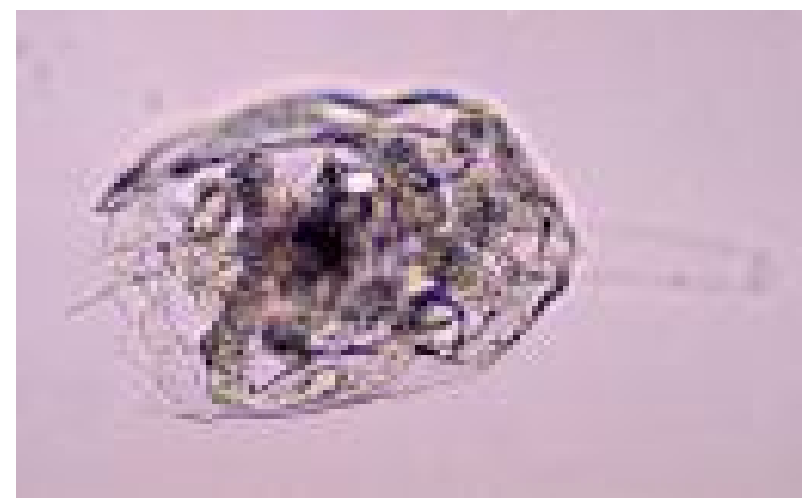

Figure 2. Spontaneously fungal infection in body of rotifers, Brachionus sp.

observations the infecting fungus was identified as a species belonging to the order Lagenidiales. Fungus was isolated by inoculating 10 infected rotifers onto PYGSagar and incubated at $25^{\circ} \mathrm{C}$.

Isolation and identification. The fungus which was purely isolated from infected bodies and eggs of rotifers, Brachionus sp. were belonging to the order Lagenidiales, and identified as a member of the genus Lagenidium because vesicles produced at zoospore production. The present isolate were maintained at $25^{\circ} \mathrm{C}$ and sub cultured onto PYGS agar at approximately monthly intervals. The morphological characteristics of the present isolates are given as follows:

\section{Lagenidium callinectes Couch}

Colonies on PYGS agar were whitish and reached $15-17 \mathrm{~mm}$ in diameter after 5 days of incubation at $25^{\circ} \mathrm{C}$. The centre was damp. Hyphae were aseptate, irregularly branched, stout, with numerous shiny rod-shaped granules, 5-35 mm width (Figure 3). Zoospore formation was observed about 12 hours after the mycelia being transferred into sterilized seawater. Masses of protoplasm flowed into the tip of the discharge tubes (Figure 4), where vesicles appeared. Each protoplasmic mass was connected in a chain with a protoplasmic thread. The volume of the vesicles increased with the continuous entrance of protoplasmic masses, division into initial zoospores and

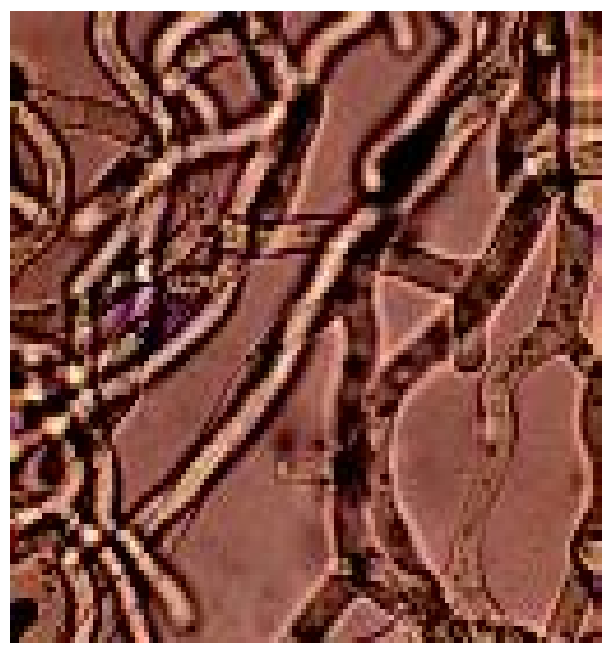

Figure 3. Lagenidium callinectes, coiled hyphae in PYGS broth 


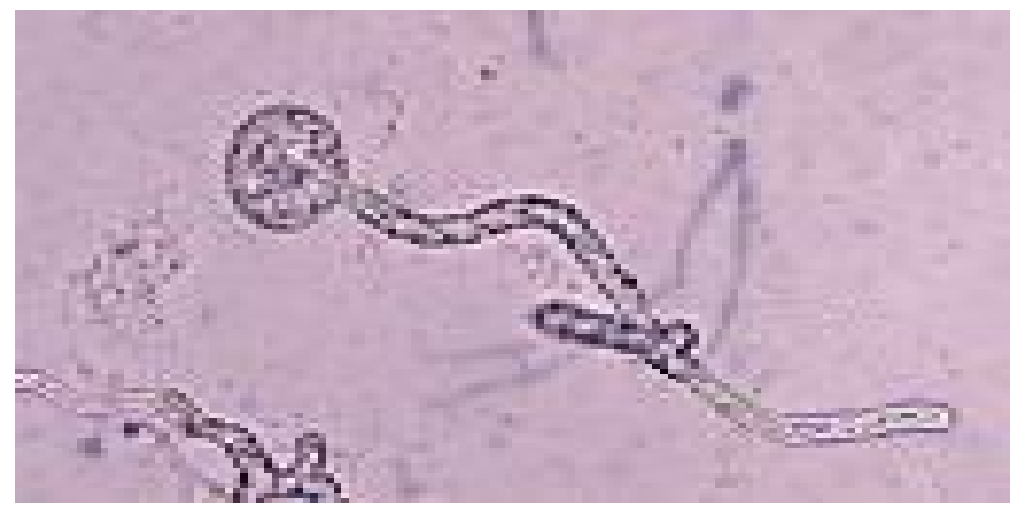

Figure 4. Vesicle formation and flow of protoplasmic masses into vesicle

active movement of the zoospores. After all of the protoplasm entered into the vesicles, flagella appeared around the protoplasm in the first 5 minutes, and individual zoospores not divided completely were recognized in 1012 minutes, swam freely inside the vesicles in 25-30 minutes and were released in 40-60 minutes.

This morphological process was observed after the time lapses. Zoospore production was successively observed up to 7 days. Mature vesicles (Figure 5) were gelatinous, globose to subglobose, 15-100 $\mathrm{mm}$ diameter. The discharged tubes were 5-20 x 30-200 mm, usually broad at the orifice. The way of zoospore liberation varied; sometimes they were released simultaneously by rupture of the vesicle, sometimes singly through a hole in the vesicle wall (Figure 6). When zoospores were discharged singly, vesicles usually persisted for a few minutes. Zoospores were monoplanetic and 5-15 x 10-17 mm, $10 \times 15$ $\mathrm{mm}$ on average. Usually they swim for 20 hours, and stop swimming over 24 hours. When encysted, they were globose to subglobose without flagella, 5-12 $\mathrm{mm}$ diameter, $8 \mathrm{~mm}$ on average. Germination was observed about 5 hours after spores had encysted. Sexual reproduction was not observed.

Specimen examined BM-2004(1) isolated from egg and $\mathrm{BH}-2004(2)$ isolated from bodies of rotifer, Brachionus sp. with a fungus infection, were obtained from milkfish hatchery on $21^{\text {st }}$ of June 2004 and from humpback grouper hatchery on $25^{\text {th }}$ of June 2004 at Gondol, Bali.

Effect of temperature on vegetative growth. The results are displayed in Table 1. Isolates BM- 2004(1) and BH- 2004(2) could grow over a wide temperature ranged from $15^{\circ} \mathrm{C}$ to $35^{\circ} \mathrm{C}$ with an optimum range $25^{\circ} \mathrm{C}$. The isolate L. callinectes ATCC 200337 as a comparison also showed the same effect. These results suggested that the organisms were adapted to tropical environment.

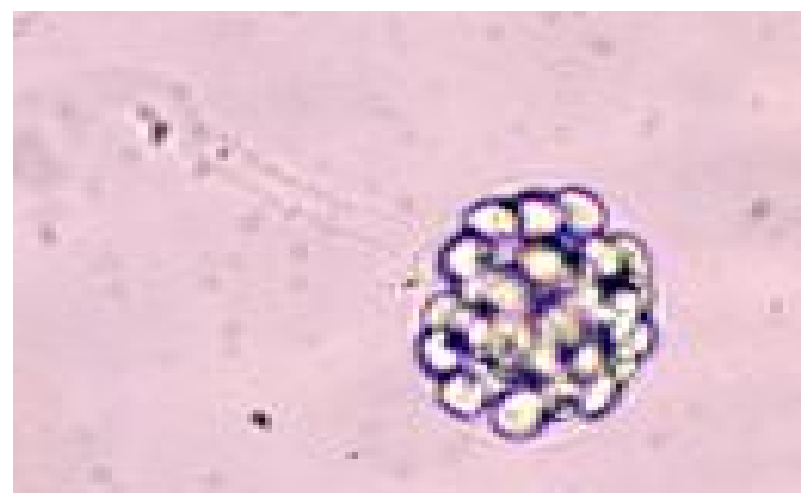

Figure 5. Mature vesicle 


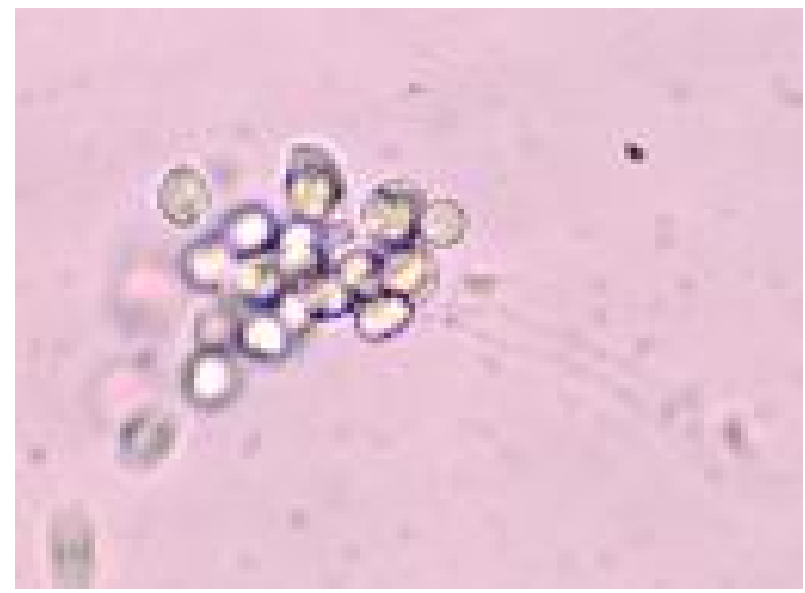

Figure 6. Zoospores released from a vesicle

Table 1. Effect of temperature on vegetative growth of isolate BM- 2004 (1) and $\mathrm{BH}-2004(2)$ in comparison with those Lagenidium callinectes ATCC 200337

\begin{tabular}{|c|c|c|c|}
\hline \multirow{2}{*}{$\begin{array}{c}\text { Temperature } \\
\left({ }^{\circ} \mathrm{C}\right)\end{array}$} & \multicolumn{3}{|c|}{ Colony radius ( $\mathrm{mm}$ ) incubated for 15 days } \\
\hline & BM-2004(1) & BH-2004(2) & $\begin{array}{l}\text { L. callinectes } \\
\text { ATCC200337 }\end{array}$ \\
\hline 10 & -2) & - & - \\
\hline 15 & 12.5 & 8.0 & 10.0 \\
\hline 20 & 30.5 & 27.0 & 25.5 \\
\hline 25 & $>60.0$ & $>60.0$ & 55.5 \\
\hline 30 & 29.5 & 28.0 & 32.5 \\
\hline 35 & 11.0 & 15.5 & 14.0 \\
\hline 40 & - & - & - \\
\hline
\end{tabular}

Remarks: 1) Isolated from egg of the swimming crab, P. pelagicus Linnaeus (Nakamura \& Hatai, 1995 ${ }^{\mathrm{b}}$ ); - ${ }^{2)}=$ no growth

Mineral requirements for vegetative growth. The results, shown in Table 2, revealed the optimum growth on PYGS agar for all isolates. The isolate BM- 2004(1) and BH2004(2) including L. callinectes ATCC 200337 could grow at various concentrations of $\mathrm{NaCl}$ and on PYG agar without seawater but not in $5.0 \% \mathrm{KCl}$.

Nutritional study for vegetative growth. Carbohydrates and derivatives capable of serving as sole carbon, nutrition and energy sources for the isolate BM- 2004(1) and $\mathrm{BH}-2004(2)$ are presented in Table 3. Both of the present isolates including $\mathrm{L}$. callinectes ATCC 200337 were able to utilize only 8 out of
26 carbohydrates and derivatives tested such as glucose, mannose, fructose, maltose, trehalose, cellobiose, dextrin and starch. Glucose and carbohydrates composed of glucose molecules, such as maltose, starch and dextrin, provided good support as carbon and nutrition sources. However, arabinose, galactose, rhamnose, sorbose and lactose were poor. Sugar alcohols were not utilized as sole carbon and nutrition sources.

\section{DISCUSSION}

Based on the above morphological characteristics, isolate BM-2004(1) and BH2004(2) were classified as a member of the 
Indonesian Aquaculture Journal Vol.2 No.1, 2007

Table 2. Effect of $\mathrm{NaCl}$ or $\mathrm{KCl}$ on vegetative growth of isolate $\mathrm{BM}-2004(1)$ and $\mathrm{BH}-2004(2)$ in comparison with those Lagenidium callinectes ATCC 200337

\begin{tabular}{lccc}
\hline \multirow{2}{*}{ Medium } & \multicolumn{2}{c}{ Colony radius (mm) incubated for 15 days } \\
\cline { 2 - 4 } & BM-2004(1) & BH-2004(2) & $\begin{array}{c}\text { L. callinectes } \\
\text { ATCC 200337 }\end{array}$ \\
\hline PYG agar + $1.0 \% \mathrm{NaCl}$ & 22.5 & 25.0 & 20.5 \\
PYG agar $+2.5 \% \mathrm{NaCl}$ & 41.0 & 50.5 & 49.5 \\
PYG agar $+5.0 \% \mathrm{NaCl}$ & 19.5 & 17.0 & 20.0 \\
PYG agar $+1.0 \% \mathrm{KCl}$ & 6.0 & 6.0 & 5.5 \\
PYG agar $+2.5 \% \mathrm{KCl}$ & 7.0 & 6.5 & 7.5 \\
PYG agar $+5.0 \% \mathrm{KCl}$ & $-2)$ & - & - \\
PYGS agar & $>60.0$ & $>60.0$ & 55.5 \\
PYG agar & 6.0 & 5.5 & 4.5 \\
\hline
\end{tabular}

Remarks: ${ }^{1)}$ Isolated from egg of the swimming crab, P. pelagicus Linnaeus (Nakamura \& Hatai, 1995 $)^{\text {b }}$ - ${ }^{2)}=$ no growth

genus Lagenidium (Oomycetes, Lagenidiales). The fungus was endobiotic and holocarpic and laterally biflagellate zoospores were produced in the vesicles (Hatai, 1989; Karling, 1981; Bland \& Amerson In Nakamura et al., 1994; Couch In Nakamura \& Hatai, 1995 ${ }^{\mathrm{b}}$ ).

Lagenidium callinectes was first described by Couch in Nakamura \& Hatai $\left(1995^{\text {b}}\right)$ on eggs of blue crab, Callinectes sapidus Rathbun, and later discovered from eggs and larvae of various crabs and shrimps (Crisp et al., 1989). L. callinectes was also discovered on surface of the marine algae including Chordaria sp. and Ectocar pus sp. (Fuller et al. in Nakamura \& Hatai, 1994). Later Nakamura \& Hatai (1995) isolated from infected zoea of the swimming crab, P. pelagicus Linnaeus. This the first report on $\mathrm{L}$. callinectes infected of the rotifer, Brachionus sp. However, Lagenidium infection on marine crustaceans culture farms, mainly on mangrove crab has been recognized in Indonesia, although the causative agents were not determined. It was considered that L. callinectes was involved in some of the infections. When the morphological characteristics of the present isolate BM2004(1) and BH- 2004(2) were compared with L. callinectes Couch in Nakamura \& Hatai (1995 ${ }^{\text {b }}$ ) and L. callinectes ATCC 200337 (Nakamura \& Hatai $\left.1995^{\mathrm{b}}\right)$, no significant differences were found.

In the present isolates, zoospores were released by rupturing of the vesicles or through a small hole in each vesicle. The former seems to be the main way of zoospore liberation for this fungus. Later when zoospores moved relatively slowly in the vesicles occur, and was also observed in L. skyline (Bian et al. 1979; Hatai, 1989). The present isolate BM- 2004 (1) and $\mathrm{BH}-2004(2)$ was close to those of $\mathrm{L}$. callinectes and L. scyllae in the dimensions of hyphae, vesicles, discharged tubes and zoospore (Bian et al., 1979; Crisp et al., 1989). L. scyllae was similar to L. callinectes except for its thermo tolerant growth and the method of zoospore liberation (Bian et al., 1979; Hatai, 1989; Couch In Nakamura \& Hatai, 1995'). Zoospores of L. scyllae were released one by one from the openings of the vesicles, or simultaneously by rapid delinquency of the vesicles (Bian et al., 1979). However, these reported both modes of liberation in $L$. callinectes isolated from eggs and bodies of the rotifer, Brachionus sp.

The fungi grew at temperature $15^{\circ} \mathrm{C}-35^{\circ} \mathrm{C}$ and optimum temperature $25^{\circ} \mathrm{C}$ of the isolate BM-2004(1) and BH- 2004(2) also L. callinectes ATCC 200337 were similar to those L. scyllae (Nakamura \& Hatai, 1995). Thermo tolerant growth was observed in L. scyllae (Bian et al., 1979), L. thermophilum (Nakamura et al., 1994), L. callinectes ATCC 200337 (Nakamura \& Hatai, $1995^{b}$ ) and both of the present isolates.

Both of the present isolates were not obligatory marine fungi, and $\mathrm{NaCl}$ could be replaced by other ions such as $\mathrm{KCl}$. However, 
Table 3. Utilization of carbohydrates and derivates of the isolate BM2004(1) and BH- 2004 (2) in comparison with those L. callinectes ATCC 200337

\begin{tabular}{|c|c|c|c|}
\hline \multirow{2}{*}{$\begin{array}{l}\text { Carbohydrates } \\
\text { and derivatives }\end{array}$} & \multicolumn{3}{|c|}{ Utilization activity ${ }^{1)}$} \\
\hline & $\begin{array}{c}\text { BM-2004 } \\
\text { (1) }\end{array}$ & $\begin{array}{l}\text { BH-2004 } \\
\text { (2) }\end{array}$ & 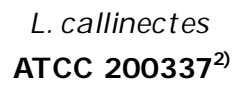 \\
\hline \multicolumn{4}{|l|}{ Monosaccharide : } \\
\hline Arabinose & -3) & - & - \\
\hline Galactose & - & - & - \\
\hline Glucose & $+++^{4)}$ & ++ & ++ \\
\hline Mannose & $++^{5)}$ & ++ & + \\
\hline Rhamnose & - & - & - \\
\hline Sorbose & - & - & - \\
\hline Xylose & - & - & - \\
\hline Fructose & $+^{6)}$ & + & + \\
\hline \multicolumn{4}{|l|}{ Disaccharides : } \\
\hline Lactose & - & - & - \\
\hline Maltose & +++ & +++ & +++ \\
\hline Trehalose & + & ++ & + \\
\hline Cellobiose & + & ++ & + \\
\hline Sucrose & - & - & - \\
\hline Mellibiose & - & - & - \\
\hline \multicolumn{4}{|l|}{ Tri-Polysaccharides : } \\
\hline Dextrin & ++ & +++ & +++ \\
\hline Melezitose & - & - & - \\
\hline Raffinose & - & - & - \\
\hline Salicin & - & - & - \\
\hline Starch & ++ & ++ & ++ \\
\hline Cellulose & - & - & - \\
\hline \multicolumn{4}{|l|}{ Sugar alcohols : } \\
\hline Dulcitol & - & - & - \\
\hline Erythriol & - & - & - \\
\hline Inositol & - & - & - \\
\hline Mannitol & - & - & - \\
\hline Sorbitol & - & - & - \\
\hline Xylitol & - & - & - \\
\hline $\begin{array}{ll}\text { Remarks: 1) Evaluated b } \\
\text { 2) Isolated fro } \\
\text { Linnaeus (N } \\
\text { 3) Not grow; } \\
\text { 4) Colony radi } \\
\text { 5) Colony radi } \\
\text { 6) Colony radi }\end{array}$ & $\begin{array}{l}\text { lony radius a } \\
\text { gg of the swir } \\
\text { mura \& Hatai, } \\
10.0 \mathrm{~mm} \text {; } \\
0 \mathrm{~mm}<10.0 \\
5 \mathrm{~mm}\end{array}$ & $\begin{array}{l}\text { er incubatic } \\
\text { ming crab, } \\
\text { (995 }) \text {; } \\
\text { nm; }\end{array}$ & $\begin{array}{l}\text { at } 25^{\circ} \mathrm{C} \text { for } 15 \mathrm{da} \\
\text { tunus pelagicus }\end{array}$ \\
\hline
\end{tabular}


Bahnweg \& Bland (1980), reported that L. callinectes did not require $\mathrm{NaCl}$, but displayed a rather broad range of good growth from $0.1 \%-3.0 \% \mathrm{NaCl}$. The rather broad tolerances to varying salinities of the fungi parasites may be of adaptive value for life in estuarine and coastal habitats (Bahnweg \& Gotelli, 1980).

The present isolate BM- 2004(1) and BH$2004(2)$ were able to utilize only 8 out of 26 carbohydrates and derivatives tested as carbon and nutrition sources. Glucose, maltose, dextrin and starch has been known provided good support as carbon and energy for both of them, but salicin, galactose and lactose, albeit poorly. Bahnweg \& Gotelli (1980) also reported L. callinectes could assimilate glucose as sole source of carbon, energy and supported meagre growth. It might have enzymes that can utilize glucose and carbohydrates composed of glucose molecules. The nutritional study may provide criteria to identify the fungus level in taxa.

\section{CONCLUSIONS}

One species of fungus member of the genus Lagenidium was isolated from infected eggs and bodies of the rotifer, Brachionus sp. cultured in hatcheries of milkfish and humpback grouper at Gondol, Bali on $21^{\text {st }}$ and $25^{\text {th }}$ June 2004. The pathogenic fungus was identified as Lagenidium callinectes. Optimum temperature for vegetative growth is $25^{\circ} \mathrm{C}$; best growth occurs in $1 \% 2.5 \%$ and $5 \% \mathrm{NaCl}$ and not grows in $5 \% \mathrm{KCl}$. However, the isolates were only capable to utilize 8 out of 26 of carbohydrates as carbon, nutrition and energy sources.

\section{ACKNOWLEDGEMENTS}

I wish to thank Slamet Haryanto, Putu Suarjana, and Sri Suratmi for their kindness to helping, preparing and observing the specimens in this experiment.

\section{REFERENCES}

Bahnweg, G. and D. Gotelli. 1980. Physiology and nutrition of Lagenidium callinectes, a fungal parasite of the blue crab (Callinectes sapidus). Botanica Marina, XXIII: 219-225.
Bahnweg, G. and C.E. Bland. 1980. Comparative physiology and nutrition of Lagenidium callinectes and Haliphthoros milfordensis, fungal parasites of marine crustaceans. Botanica Marina, XXIII: 689-698.

Barron, G.L. 1989. New species and new records of fungi that attack microscopic animals. Can. J. Bot., 67: 267-271.

Bian, B.Z., K. Hatai, G.L. Po, and S. Egusa. 1979. Studies on the fungal diseases in crustaceans. I. Lagenidium scyllae sp. nov. isolated from cultivated ova and larvae of the mangrove crab (Scylla serrata). Trans. Mycol. Soc. Japan, 20: 115-124.

Comps, M., B. Menu, and V. Moreau. 1993. Massive infections with fungus of the rotifer Brachionus plicatilis. Bull. Eur. Ass. Fish Pathol., 13: 28-29.

Crisp, L.M. Jr., C.E. Bland, and G. Bahnweg. 1989. Biosystematics and distribution of Lagenidium callinectes, a fungal pathogen of marine crustaceans. Mycologia, 81: 709-716.

Hatai, K. 1989. Fungal pathogens and parasites of aquatic animals. In "Methods for microbiological examination of fish and shell fish", (Eds. by Austin, B. and Austin, B.). p. 250-258. Ellis Horwood Limited, London.

Karling, J.S. 1981. "Predominantly holocarpic and eurocarpicsimple biflagellate Phycomycetes". Strauss and Cramer, Hirschberg, 252 pp.

Nakamura, K., S. Wada, K. Hatai, and T. Sugimoto. 1994. Lagenidium myophilum infection in the coonstripe shrimp, Pandalus hypsinotus. Mycoscience, 35: 99-104.

Nakamura, K. and K. Hatai. 1994. Atkinsiella parasitica sp. nov. isolated from rotifer, Brachionus plicatilis. Mycoscience, 35: 383-389.

Nakamura, K., M. Nakamura, and K. Hatai. 1995a. Atkinsiella infection in the rotifer Brachionus plicatilis. Mycoscience, 35: 291-294.

Nakamura, K. and K. Hatai. 1995 b. Three species of Lagenidiales isolated from the eggs and zoea of the swimming crab Portunus pelagicus. Mycoscience, 36: 87-95. Legend 